\title{
Evaluation of Genetic Diversity among Persimmon Cultivars (Diospyros kaki Thunb.) Using Microsatellite Markers
}

\author{
Ji Hyeon Hwang, Yu-Ok Park', Sung-Churl Kim', Yong-Jae Lee, Jum Soon Kang, \\ Young Whan Choi, Beung-Gu Son and Young-Hoon Park*
}

Department of Horticultural Bioscience, Pusan National University, Miryang 627-706, Korea

${ }^{1}$ Sweet Persimmon Research Institute, Gyeongnam Agricultural Research \& Extension Service, Gimhae 621-802, Korea

Received March 30, 2010 / Accepted April 9, 2010

\begin{abstract}
The genetic diversity among 48 persimmon (Diospyros kaki Thunb.) accessions, indigenous in Korea and introduced from Japan and China, was evaluated by using simple sequence repeat (SSR) markers. From 20 SSR primer sets, a total of 114 polymorphic markers were detected among 12 pollination-constant non-astringent (PCNA), 13 pollination-variant non-astringent (PVNA), 15 pollination-variant astringent (PVA), and 8 pollination-constant astringent (PCA) cultivars. Analysis of pair-wise genetic similarity coefficient (Nei-Li) and unweighted pair-group method with arithmetic averaging (UPGMA) clustering revealed two main clusters and four subclusters for cluster I. The subclustering pattern was in accordance with the classification of persimmon cultivars based on the nature of astringency loss. Phenetic relationships among the subclusters showed a closer relatedness of the PCNA group with the PVNA group, and the PVA with the PCA group. Genetic similarity co-efficiency was 0.499 on average and the highest (0.954) similarity was observed between 'Cheongdo-Bansi' and 'Haman-Bansi'. The similarity was lowest (0.192) between 'Damopan'and 'Atago'. Identification of each cultivar with the execption of 'Cheongdo-Bansi' and 'Gyeongsan-Bansi' was possible based on the SSR fingerprints, suggesting that these SSR markers are a useful tool for protecting intellectual property on newly developed cultivars.
\end{abstract}

Key words : Diospyros kaki, microsatellite, simple sequence repeat, genetic distance

\section{서 론}

감나무는 감나무과에 속하며, 학명은 Diospyros kaki THUNB. var. domestica MAK이다. 전세계에 분포하는 감나무 속(Diospyros L.) 식물은 약 190여종이며 이 중 과수로 이용되 고 있는 것은 감(Diospyros kaki THUNB), 고욤(Diospyros louts L.), 미국감(Diospyros virginiana L.), 유시(Diospyros oleifera Cheng) 등 4 종이다[10].

감은 크게 단감과 떫은감으로 구분한다. 단감은 과실이 성 숙함에 따라 떫은 맛의 원인인 감 탄닌이 물에 녹아 떫은맛을 느끼게 하는 가용성탄닌에서 물에 녹지 않는 불용성탄닌으로 변한다[6,17]. 따라서 소비자의 입에 들어갔을 때 떫은 맛이 완전히 제거되고 단맛만이 남는다. 이러한 단감과 떫은감은 과실 내의 종자와 감삽(달고 떫음)과의 관계로 4 가지 그룹으로 분류한다. 즉, 단감에는 완전단감(pollination constant non-astringency, PCNA)과 불완전단감(pollination variant non-astringency, PVNA), 떫은감에도 완전떫은감(pollination constant astringency, PCA)과 불완전떫은감(pollination variant astringency, PVA)이 있다[7,18]. 완전단감은 종자의 유무에 관

*Corresponding author

Tel : +82-55-350-5525, Fax : +82-55-350-5529

E-mail : ypark@pusan.ac.kr
계없이 지속적으로 떫은맛을 잃기 때문에 단감재배 시 인위적 으로 수분하지 않아도 떫은맛을 잃어 단감이 된다. 또한 불완 전단감은 종자를 가짐으로써 과육의 색이 갈변됨과 동시에 떫은맛을 잃게 된다. 따라서 완전단감 품종은 단감의 과육색 을 유지함과 동시에 떫은 맛이 없어 상업적인 측면에서 재배 농가에게 매우 중요한 품종이다.

현재 국내 단감생산에 이용되는 품종은 '부유(Fuyu)','서촌 조생(Nishimurawase) ${ }^{\prime}$ 등과 같은 일본품종이 대부분이며, 종 자산업법의 신품종보호제도 실시에 따른 일본 단감품종에 대 한 로열티 지급으로 인해 국내 단감품종의 개발과 보급이 시 급한 실정이다. 신품종 육성을 위해서는 육종에 이용되는 유 전자원 선발 및 유전적 다양성의 확보와 이들에 대한 정확한 유전적 정보를 파악하는 것이 매우 중요하다. 더불어 신품종 육성시 품종에 대한 지적 재산권을 보호할 수 있는 품종 판별 기술 또한 마련되어야 한다.

최근 들어서는 DNA 마커를 이용한 육종선발 및 품종분류 가 여러 작물에서 이용되고 있다[4,9,13]. DNA 마커는 유전현 상의 본질인 $\mathrm{DNA}$ 의 염기서열 차이를 대상으로 하기 때문에 개체간 변이 수준이 매우 높으며, 식물의 발육단계와 관계없 이 안정적으로 관찰되며, 모든 조직에서 탐지할 수 있다. 또한 환경에 영향을 받지 않고, 유전자간의 상위작용이나 다면발현 에 의한 영향을 받지 않아 보다 정확한 선발과 유전학적 분류 
가 가능하다 $[1,5,16]$. DNA 마커에는 RAPD (random amplified polymorphic DNA), RFLP (restriction fragment length polymorphism), AFLP (amplified fragment length polymorphism) 및 microsatellites (simple sequence repeat, SSR) 등의 다양한 기법이 있는데 이 중 SSR 마커는 품종 또는 개체 간 다양성이 상대적으로 높고, 마커 검정 절차 또한 매우 신속 하고 비용이 절감되는 장점을 지니고 있다.

따라서, 본 연구는 최근 감으로부터 개발된 SSR 마커를 이 용하여, 주요 육종재료로 쓰이고 있는 일본과 중국의 도입종 및 국내 재래감 품종들간 유전적 다양성과 유연관계를 평가하 고 단감 품종의 육성 및 품종보호를 위한 품종 판별용 마커개 발을 위한 기초자료를 제공하고자 실시하였다.

\section{재료 및 방법}

\section{식물 재료}

SSR 마커를 이용한 감 품종간 유연관계분석을 위해 경남단 감육종연구소(창원) 에서 보존 중인 국내품종 14 점, 중국품종 1점, 일본품종 33점을 포함하여 총 48 점을 선발하여 이용하였 다(Table 1).

\section{$\mathrm{DNA}$ 추출}

$-70^{\circ} \mathrm{C}$ 에서 동결 보존한 단감 잎 3-5 $\mathrm{g}$ 을 잘게 썰어 막자사발 에 넣고 액체질소를 사용하여 곱게 간 분말에 $65^{\circ} \mathrm{C}$ 의 extraction buffer $15 \mathrm{ml}$ 를 첨가하여 잘 혼합한 다음, $65^{\circ} \mathrm{C}$ waterbath에 넣고 15 분 간격으로 혼합하면서 60 분 동안 반응시켰다. 그 다음 chloroform-isoamyl alcohol (24:1)용액 $10 \mathrm{ml}$ 를 첨가 한 후 10 분간 잘 혼합한 후, $12,000 \times g$ 에서 15 분간 원심분리 하였다. $13 \mathrm{ml}$ 정도의 상층액을 새로운 tube에 옮긴 다음 isoprophanol 용액 $13 \mathrm{ml}$ 를 첨가 후 잘 혼합하여 1시간 동안 실온 에서 반응시켰다. 이를 $12,000 \times g$ 에서 $25^{\circ} \mathrm{C}$ 로 15 분간 원심분 리 시키고 난 뒤 생긴 pellet을 $70 \%$ ethanol 용액 $3 \mathrm{ml}$ 로 세척 하였다.

Pellet을 5 분간 완전히 건조 시킨 후 TE buffer (Tris $1 \mathrm{M}$, EDTA $0.5 \mathrm{M}$ )용액 $0.7 \mathrm{ml}$ 를 넣어 녹인 뒤 $10 \mathrm{mg} / \mathrm{ml}$ RNase 용액 $5 \mathrm{ul}$ 를 첨가 한 뒤 $37^{\circ} \mathrm{C}$ 에 30 분간 반응 시켰다. 반응 시킨 용액을 $1.5 \mathrm{ml}$ microcentrifuge tube에 옮ㄱ 담고, phenol 25:24:1 용액 $0.65 \mathrm{ml}$ 를 첨가 한 후 5 분간 흔들어 준 다음 $12,000 \times g$ 에서 $25^{\circ} \mathrm{C}$ 로 15 분간 원심분리 하였다. 가라 앉은 pellet을 제외한 상층액 $0.6 \mathrm{ml}$ 를 새로운 tube로 옮기고 chilled isoprophanol 용액을 $0.5 \mathrm{ml}$ 첨가 한 후 몇 번 흔들어 주고,

Table 1. List of 48 persimmon cultivars used for the evaluation of genetic relationship by SSR markers

\begin{tabular}{|c|c|c|c|c|c|c|c|}
\hline Sample no. & Cultivar $^{\mathrm{a}}$ & Type $^{b}$ & Origin & Entry no. & Cultivar $^{\mathrm{a}}$ & Type $^{b}$ & Origin \\
\hline 1 & Toyouichi* & PCNA & Japan & 25 & $3-225$ & PVNA & Korea \\
\hline 2 & Fujiwaragosho* & PCNA & Japan & 26 & Tonewase & PVA & Japan \\
\hline 3 & Jiro* & PCNA & Japan & 27 & Sugitawase & PVA & Japan \\
\hline 4 & Midai* & PCNA & Japan & 28 & Superhiratanenashi & PVA & Japan \\
\hline 5 & Mammoth* & PCNA & Japan & 29 & O-tanenashi & PVA & Japan \\
\hline 6 & Sunami* & PCNA & Japan & 30 & Hiratanenashi & PVA & Japan \\
\hline 7 & MazumotowaseFuyu* & PCNA & Japan & 31 & O-miyawase & PVA & Korea \\
\hline 8 & Fuyu* & PCNA & Japan & 32 & Yeuseung-Sagoksi & PVA & Korea \\
\hline 9 & Ichikikeijiro* & PCNA & Japan & 33 & Myeongju-Kojongsi & PVA & Korea \\
\hline 10 & Suruga* & PCNA & Japan & 34 & Cheongdo-Bansi & PVA & Korea \\
\hline 11 & Okugosho* & PCNA & Japan & 35 & Gyeongsan-Bansi & PVA & Korea \\
\hline 12 & $104^{*}$ & PCNA & Japan & 36 & Haman-Mulgam & PVA & Korea \\
\hline 13 & Johongsi* & PVNA & Japan & 37 & Haman-Bansi & PVA & Korea \\
\hline 14 & Nishimurawase* & PVNA & Japan & 38 & Goesan-Durigam & PVA & Korea \\
\hline 15 & Migatanigosho* & PVNA & Japan & 39 & 80Eugeon & PVA & Korea \\
\hline 16 & Haschiuri* & PVNA & Japan & 40 & Sangju-Dungsi & PVA & Korea \\
\hline 17 & Amahyakume & PVNA & Japan & 41 & Damopan & PCA & China \\
\hline 18 & Koharu & PVNA & Japan & 42 & Wasezizya & PCA & Japan \\
\hline 19 & Kyara & PVNA & Japan & 43 & Atago & PCA & Japan \\
\hline 20 & Zenjimaru & PVNA & Japan & 44 & Wasesaijo & PCA & Japan \\
\hline 21 & Sanggokuitsy & PVNA & Japan & 45 & Gogseung-Tabaegam & PCA & Korea \\
\hline 22 & Akagaki & PVNA & Japan & 46 & Sancheong-Danseongsi & PCA & Korea \\
\hline 23 & Tenrubou & PVNA & Japan & 47 & Sancheong-Kojongsi & PCA & Korea \\
\hline 24 & Toyoga & PVNA & Japan & 48 & Yeongdeong-Weolhasi & PCA & Korea \\
\hline
\end{tabular}

a * indicates 16 samples that were pretested for PCR with 20 SSR primer sets.

${ }^{\mathrm{b}} \mathrm{PCNA}$, pollination-constant non-astringent; PVNA, pollination-variant non-astringent; PVA, pollination-variant astringent; and PCA, Pollination-constant astringent. 
DNA pellet이 생기는지 확인 한 뒤 $12,000 \times g$ 에서 $4^{\circ} \mathrm{C}$ 로 15 분 간 원심분리 하였다. 상등액을 버리고 난 뒤 DNA pellet을 $70 \%$ ethanol 용액 $1 \mathrm{ml}$ 로 세척한 다음, 5 분간 건조 시킨 뒤 $12,000 \times g$ 에서 $4^{\circ} \mathrm{C}$ 로 5 분간 원심분리 한 후 ethanol을 완전히 제거 하고 15 분간 실온에 건조 시켰다. 1 0.7 ml의 TE buffer에 DNA pellet을 녹인 뒤 Nano-drop 1000 (Thermo Scientific, USA) 분광광도계와 전기영동으로 DNA를 정량 분석하였다.

\section{$\mathrm{SSR}$ 마커 분석}

SSR 마커 다형성 분석을 위해 Soriano 등[15]이 개발한 20개 의 SSR primer set (Table 2)을 사용하였다. 먼저 16개 품종의 $\mathrm{DNA}$ 샘플을 이용하여 1차 PCR 검정을 하였으며, $\mathrm{PCR}$ 이 성 공적으로 이루어졌음을 확인 후 48 개 모든 공시 품종에 대한
2차 PCR 검정을 하였다.

PCR 용액의 조성은 $20 \mathrm{ng}$ 의 genomic DNA, 10X PCR buffer, $25 \mathrm{mM} \mathrm{MgCl}$, $10 \mathrm{mM}$ dNTPs, $50 \mathrm{uM}$ forward primer, $50 \mathrm{uM}$ reverse primer, $5 \mathrm{U} / \mathrm{ul}$ Taq DNA polymerase $0.2 \mathrm{ul}$ (solgent, 대전)를 혼합하여 이용하였다. DNA 증폭은 Bio-RAD사의 $\mathrm{MyCycler}{ }^{\mathrm{TM}}$ 을 사용하여, Hot step을 $95^{\circ} \mathrm{C}$ 에서 2 분간 실시하였고, $94^{\circ} \mathrm{C}$ 에서 15 초간 denaturation, $60^{\circ} \mathrm{C}$ 에서 부터 30초씩 $0.5^{\circ} \mathrm{C}$ 떨어지도록 touch down으로 $10 \mathrm{cycle}$ 하여 $55^{\circ} \mathrm{C}$ 까지 annealing 시켜 각 primer를 binding 시킨 후 $72^{\circ} \mathrm{C}$ 에 서 1 분간 extension 시켰다. 그 다음 다시 $94^{\circ} \mathrm{C}$ 에서 15 초간 denaturation, $55^{\circ} \mathrm{C}$ 에서 30 초간 annealing, $72^{\circ} \mathrm{C}$ 에서 1 분간 extension의 과정을 35 회 반복하였고, 최종적으로 $72^{\circ} \mathrm{C}$ 에서 3 분간 extension을 수행하였다.

Table 2. DNA polymorphisms among 48 persimmon cultivars revealed by 15 SSR primers

\begin{tabular}{|c|c|c|c|c|c|c|}
\hline Primer & Primer sequence $\left(5^{\prime}-3^{\prime}\right)$ & $\begin{array}{l}\text { Expected } \\
\text { Size (bp) }\end{array}$ & $\begin{array}{l}\text { observed } \\
\text { size }(b p)\end{array}$ & $\begin{array}{l}\text { Total no. } \\
\text { of bands }\end{array}$ & $\begin{array}{c}\text { No. of } \\
\text { polymorphic bands }\end{array}$ & $\begin{array}{l}\text { Polymorphism } \\
\text { rate }^{\mathrm{a}}\end{array}$ \\
\hline $\begin{array}{l}\text { ssrDK04/ } \\
\text { DQ097472 }\end{array}$ & $\begin{array}{l}\text { CATTTGAAAGCAGTCGTCCA/ } \\
\text { GCGCCAAATCATTGCTATCT }\end{array}$ & 344 & $300-400$ & 4 & 3 & 0.75 \\
\hline $\begin{array}{l}\text { ssrDK06/ } \\
\text { DQ097474 }\end{array}$ & $\begin{array}{l}\text { CGGCATGAAGGAATAAGGAA/ } \\
\text { GCTCACATTCCAACCAATCA }\end{array}$ & 165 & $120-200$ & 10 & 10 & 1.00 \\
\hline $\begin{array}{l}\text { ssrDK08/ } \\
\text { DQ097476 }\end{array}$ & $\begin{array}{l}\text { GGCATTAGACTTGGCGAAAG/ } \\
\text { TTTTTCATCCATGCCACTGA }\end{array}$ & 187 & $170-220$ & 9 & 9 & 1.00 \\
\hline $\begin{array}{l}\text { ssrDK12/ } \\
\text { DQ097480 }\end{array}$ & $\begin{array}{l}\text { AGATGGAGTGACAGAGACTG/ } \\
\text { CCCCTTAAGTCTTAGCTAATTAC }\end{array}$ & 165 & $150-210$ & 11 & 11 & 1.00 \\
\hline $\begin{array}{l}\text { ssrDK13/ } \\
\text { DQ097481 }\end{array}$ & $\begin{array}{l}\text { GTAATTAGCTAAGACTTAAGGGG/ } \\
\text { TGCTACAACAACTGGAAGAC }\end{array}$ & 141 & $120-210$ & 6 & 6 & 1.00 \\
\hline $\begin{array}{l}\text { ssrDK14/ } \\
\text { DQ097482 }\end{array}$ & $\begin{array}{l}\text { GTGAAGGAACCCCATAGAA/ } \\
\text { CCATCATCAGGTAGGAGAGA }\end{array}$ & 160 & $160-200$ & 4 & 4 & 1.00 \\
\hline $\begin{array}{l}\text { ssrDK16/ } \\
\text { DQ097484 }\end{array}$ & $\begin{array}{l}\text { ACTACAACGGCGGTGAGAAC/ } \\
\text { GTCCTTCACTTCCCGCATT }\end{array}$ & 153 & $120-180$ & 9 & 9 & 1.00 \\
\hline $\begin{array}{l}\text { ssrDK22/ } \\
\text { DQ097490 }\end{array}$ & $\begin{array}{l}\text { ATGAGAGAGAGAGAATGATTGATGC/ } \\
\text { CATTTTGCACGCAGTGAGAT }\end{array}$ & 150 & $100-230$ & 6 & 5 & 0.83 \\
\hline $\begin{array}{l}\text { ssrDK24/ } \\
\text { DQ097492 }\end{array}$ & $\begin{array}{l}\text { GAACCAACAAAACACAGAAA/ } \\
\text { AATAACTCCGTTTCTCTCCA }\end{array}$ & 173 & $170-200$ & 4 & 4 & 1.00 \\
\hline $\begin{array}{l}\text { ssrDK25/ } \\
\text { DQ097493 }\end{array}$ & $\begin{array}{l}\text { GGGGTAATATGAATTGAATC/ } \\
\text { CTCAGAGAGGAGAAGAAATAG }\end{array}$ & 253 & $200-260$ & 12 & 12 & 1.00 \\
\hline $\begin{array}{l}\text { ssrDK27/ } \\
\text { DQ097495 }\end{array}$ & $\begin{array}{l}\text { AGCACTGTAATTCTCCTCGT/ } \\
\text { AAAGGGCAGCTATAAAAGAA }\end{array}$ & 171 & $160-260$ & 3 & 3 & 1.00 \\
\hline $\begin{array}{l}\text { ssrDK29/ } \\
\text { DQ097497 }\end{array}$ & $\begin{array}{l}\text { ATCATGAGATCAGAGCCGTC/ } \\
\text { CACGTTAACGTTACGGAACA }\end{array}$ & 131 & $110-160$ & 8 & 8 & 1.00 \\
\hline $\begin{array}{l}\text { ssrDK30/ } \\
\text { DQ097498 }\end{array}$ & $\begin{array}{l}\text { TGGTGATCGTGGTAGTGGTT/ } \\
\text { GGCCTAATCTCTGTCCATCC }\end{array}$ & 157 & $150-200$ & 13 & 13 & 1.00 \\
\hline $\begin{array}{l}\text { ssrDK31/ } \\
\text { DQ097499 }\end{array}$ & $\begin{array}{l}\text { AGTTCTTGCGATGGGATTTG/ } \\
\text { GATGAGATGGGCTGATTGCT }\end{array}$ & 190 & $180-210$ & 6 & 6 & 1.00 \\
\hline $\begin{array}{l}\text { ssrDK36/ } \\
\text { DQ097504 }\end{array}$ & $\begin{array}{l}\text { GGGAAGAACAAAGAGAACTG/ } \\
\text { ACGAAGTTGTAATCCTGAGC }\end{array}$ & 227 & $200-240$ & 9 & 9 & 1.00 \\
\hline
\end{tabular}

${ }^{a}$ Polymorphism rate of each SSR primer set was calculated as a ratio of polymorphic bands in the number of total bands. 
전기영동은 1 차 $\mathrm{PCR}$ 검정시에는 $2.5 \%$ Agaroese gel (Certified $^{\mathrm{TM}}$ Molecular Biology, Biored, USA)을, 2차 PCR 검 정시에는 $\mathrm{PCR}$ 밴드의 분리 효율이 더욱 높은 $2.5 \% \mathrm{SFR}^{\mathrm{TM}}$ agarose (Amresco, USA) gel을 사용하여 $110 \mathrm{~V}$ 에서 약 2 3시 간 동안 수행하였다, $\mathrm{PCR}$ 생성물은 EtBr로 stain 시킨 후 UV light로 확인 하였다.

\section{유연관계 분석}

$\mathrm{PCR}$ 에 의해 증폭된 산물을 $2.5 \%$ agarose gel에서 분리한 후 분자량 확인용 $100 \mathrm{bp}$ DNA ladder band를 기준으로 하여 각 SSR 마커의 정확한 band 위치를 확인하였다. 특정 분자량 의 band가 있는 것을 ' 1 ' 없는 것을 ' 0 '으로 하여 data matrix를 작성하여 NTSYS-pc software (version 2.02k) [14]에 의해 유 전적 유사도 분석에 이용하였다.

품종간 유전적 유연관계를 보여주는 dendrogram은 유전 적 거리값을 기초로 비가중평균결합법(UPGMA)을 사용한 SHAN clustering 방법으로 작성하였다[12].

\section{결과 및 고찰}

총 20개의 감 SSR primer set을 사용하여 완전단감(PCNA) 12품종, 불완전단감(PVNA) 13품종, 불완전 떫은감(PVA) 15 품종, 완전 떫은감(PCA) 8 품종 등, 총 48 개 유전자원의 유전적 연관성을 분석 하였다.

완전단감(sample no. 1-12)과 불완전 단감(sample no. 1316)으로 구성 된 16 개 품종만을 대상으로 한 1 차 PCR 검정결 과, 20개의 primer set 모두에서 PCR 증폭이 성공적으로 이루 어졌으며, PCR 산물(대립유전자) 또한 예상되었던 분자량 범 위 내에 있었다[15]. 품종간 다형성 분석결과에서는 본 실험의 전기영동 방식으로는 분석이 매우 어려웠던 5개의 primer set 을 제외한 15 개 primer set에서 평균 3.5개의 다형성 밴드가 관찰되었으며, $s s r \mathrm{DK} 22 / \mathrm{DQ} 097490$ 에서 6개의 다형성 밴드가 관찰되어 가장 높은 다형성율을 보였다.

1 차 PCR 검정에서 뚜렷한 다형성이 관찰된 15 개 primer set을 이용하여 48 개의 감 품종에 대한 2차 PCR 검정을 수행하 였다. 그 결과, 총 114 개의 PCR 밴드가 확인 되었고, 이 중 112 개가 품종간 다형성을 나타냈다(Table 2, Fig. 1). 각 유전좌별 로는 최소 3개(ssrDK27/DQ097495)에서 최대 13개(ssrDK30/
$\mathrm{DQ} 097498$ )까지 확인 되었으며, primer 당 평균 7.6개의 대립 인자가 확인되었다(Table 2).

총 114 개 PCR 밴드를 대상으로 48 개 품종 간 유연관계를 분석한 결과, 'Dice' 유사도 값의 전체 범위는 $0.192 ~ 0.954$ 였으 며, 평균 유사도의 값은 0.499 였다. 품종간 가장 높은 유사도 값(0.954)를 나타낸 것은 '청도반시(Cheongdo-Bansi)'와 '함안 반시(Haman-Bansi)' 였고, 가장 낮은 유사도 값(0.192)을 나타 낸 것은 '대마반(Damopan)'과 '애탕(Atago)'이었다. 상대적으 로 낮은 유사도 지수는 본 실험재료로 이용된 품종의 기원이 국가적으로 다를 뿐 아니라, 유전적 조성에 있어서도 매우 차 이가 있음을 의미한다.

DICE 유사계수에 기초한 비가중평균결합법(UPGMA)의 집괴분석 결과 48 개 품종들은 크게 2 개의 그룹(cluster)으로 나뉘어졌으며, 제 1 cluster는 다시 4 개의 subcluster를 형성하 였다(Fig. 2). 제 1 subcluster는 대부분 완전 단감 품종들로 구성되었는데, 크게 '부유(Fuyu)'군과 '어소(Gosho)'군, '차랑 (Jiro)'군으로나누어졌다.'부유(Fuyu)'군에서는 '쓰나미 (Sunami)'와 '부유(Fuyu)'가 0.89의 유사도값을 가져 가장 가 까웠으며, 그 다음으로 '쓰나미(Sunami)'와 '송본조생부유 (MazumotowaseFuyu)'가 0.87로 가까웠다. 반면, '일목계차랑 (Ichikikeijiro)'과 '등원어소(Fujiwaragosho)'가 0.43으로 가장 낮은 유사도를 가졌다. '차랑(Jiro)'군에서 '차랑(Jiro)'과 그의 아조변이인 일목계차랑(Ichikikeijiro)의 유사도는 0.70 이었다. '송본조생부유(MazumotowaseFuyu)'와 '쓰나미(Sunami)'는 '부유(Fuyu)'의 아조변이종이며 '차랑(Jiro)'과 '조홍시 (Johongsi)'와 함께 같은 군으로 묶인 것은 나무의 수세나 과실 의 무게, 형태, 과실의 갈색반점, 성숙시기와 같은 생태적 특징 의 유사성을 비교하였을 때 그 근거를 추론할 수 있다.준하 (Suruga)'는 '화어소(Hanagosho') 와 '만어소(Okugosho'를 교 배한 것으로 '만어소(Okugosho)'와 0.72의 비교적 높은 유사 도를 나타냈다. ' 104 '는 1998년 창원 북면에서 수집한 계통으 로 품종명칭등록을 추진하였으나 출처가 불분명하여 보류중 에 있으나, '맘모스(Mammoth)'와 0.82, '차랑(Jiro)'과 0.72로 높은 유사도 값을 나타낸 것을 보면 일본원산인 품종이 국내 로 도입되어 정착한 것으로 추정된다.

제 2 subcluster에는 대부분 불완전단감으로 구성되었으며, 불완전 떫은감인 '애탕(Atago)'과'조생사사(Wasezizya)'도 포 함되었다. '서촌조생(Nishimurawase)' 과 '어부(Koharu)'가

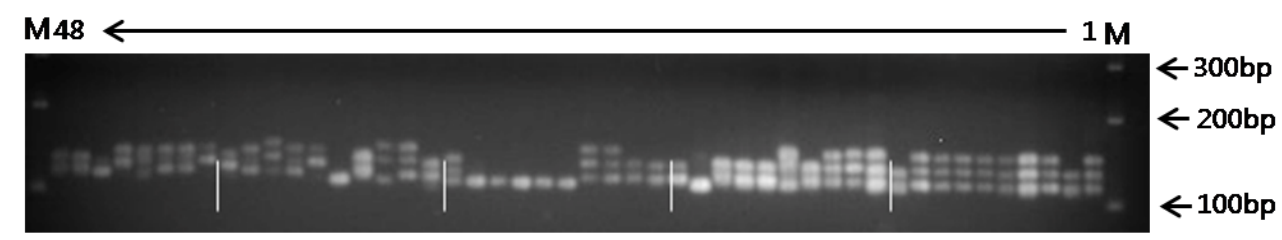

Fig. 1. Agarose gel image showing PCR products amplified by SSR primer ssrDK30/DQ097498 from persimmon cultivars. From the right, each lane represents a cultivar designated by Entry no. 1 to 48 as shown in Table.1. M, size standard marker. 


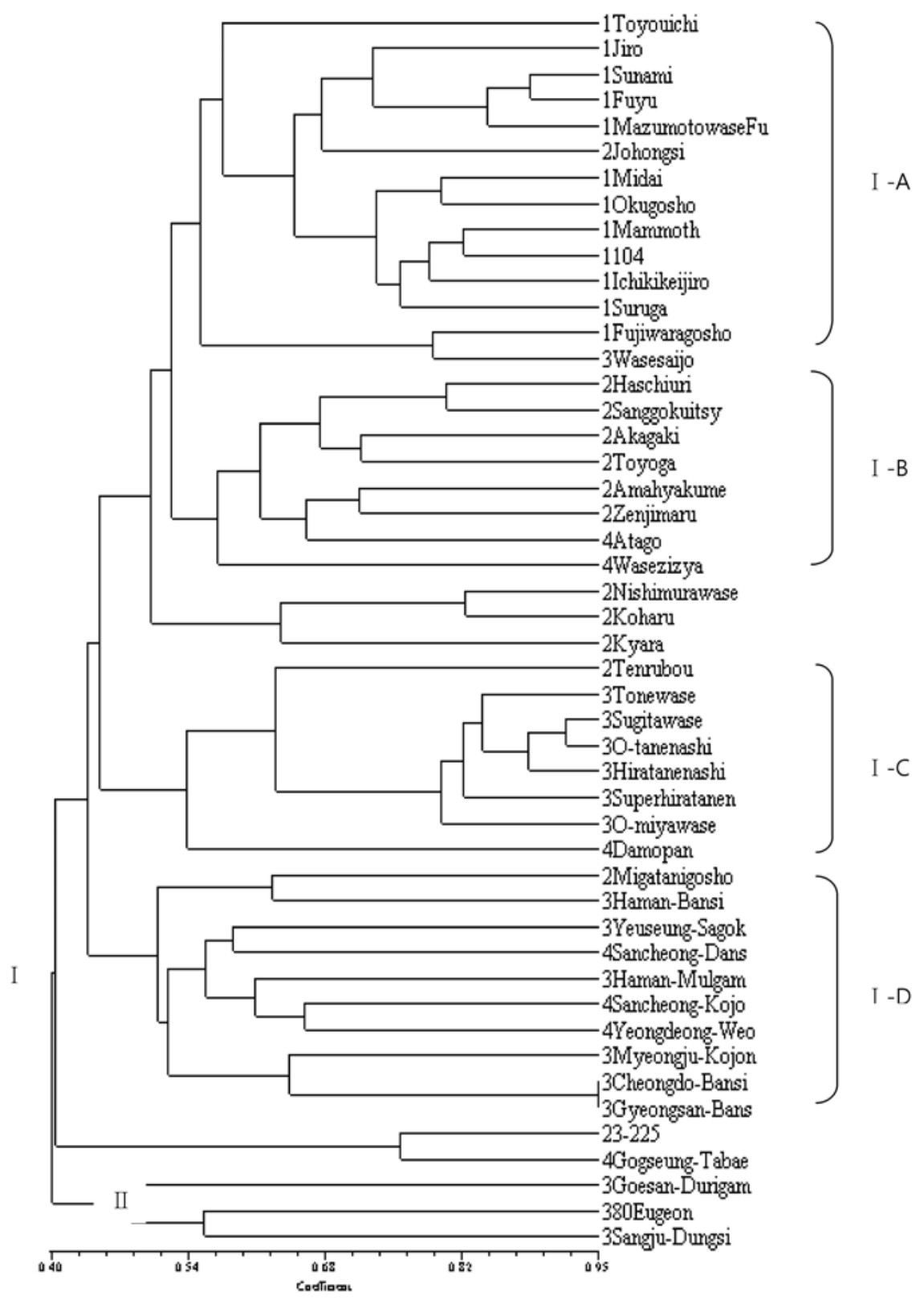

Fig. 2. Dandrogram of 48 persimmon cultivars obtained by UPGMA cluster analysis based on Nei-Li's similarity coefficient.

0.82로 유전적으로 가장 가까운 유사도를 나타냈고, '서촌조생 (Nishimurawase)'과 '적시(Akagaki)'는 0.57의 낮은 유사도를 나타냈다. 하지만 '서촌조생(Nishimurawase)'은 극조생의 우 량단감으로 '부유(Fuyu)'와 '적시(Akagaki)'의 자연교잡에서 얻 어진 우연실생으로 추정이 된다. '서촌조생(Nishimurawase)'은 수꽃이 함께 핀다는 점에서 '적시(Akagaki)'와 유사하며, 숙기 나 형태적으로도 비슷하다. 따라서 SSR 마커의 유사도지수로 는 '서촌조생(Nishimurawase)'과 '어부(Koharu)'가 더 가깝지 만 형태형질적으로는 '서촌조생(Nishimurawase)'과 '적시 (Akagaki)'가 가깝게 보여지는데, 이러한 결과는 RAPD 마커 를 사용한 분석에서도 보고되었다[8]. 그 다음으로 '삼국일
(Sanggokuitsy)'과 '하찌우리(Haschiuri)'가 0.80으로 높은 유 사도를 나타냈으며 '가라(Kyara)'와 '적시(Akagaki)'가 0.35로 가장 낮은 유사도를 보였다.

제 3 subcluster는 불완전 단감인 '천용방(Tenrubou)'과 완 전 떫은감인 '대마반(Damopan)'을 제외하고 모두 '평핵무 (Hiratanenashi)'의 가지변이나 아조변이에 의해 생긴 불완전 떫은감으로 구성되었다. 이들 6개 불완전 떫은감 품종들은 과 색, 과형, 숙기 등 형태형질적으로 구분이 힘들 정도로 비슷한 데, 품종간 유사도 지수 또한 0.75 0.92로 상당히 높게 나타났 다. 반면에, '천용방(Tenrubou)'과 '대마반(Damopan)'의 유사 도가 0.45 로 가장 낮았다. 중국 원산인 '대마반(Damopan)'은 
우리나라 떫은감 품종들보다는 일본 품종들과 더 밀접한 유연 관계를 나타냈는데 이는 AFLP를 이용한 국내 떫은감의 유연 관계분석 결과 중 일부와 일치한다[2].

제 4 subcluster에서는 국내 재래종 완전떫은감 3 품종과 불완전 떫은감 6 품종으로 구성되었다. 국내 재래감은 대부분 떫은 감이며, 주로 과실형태, 육질, 과피특성, 지역명 등 몇가 지 형태형질에 의해 불려졌기 때문에 이명동종 또는 동명이종 이 많다[3,11]. '산청고종시(Sancheong-Kojongsi)'와 '산청단성 시(Sancheong-Danseongsi)'는 0.53의 유사도를, '의성사곡시 (Yeuseung-Sagoksi)'와 '영동월하시(Yeongdeong-Weolhasi)'는 0.62 의 유사도 나타냈다. 가장 높은 유연관계(0.95)는 불완전 떫 은감인 '청도반시(Cheongdo-Bansi)'와 '경산반시(GyeongsanBansi)'에서 나타났다. 또한 제 1 cluster의 가장 외각에 위치한 '3-225'은 완전단감인 '송본조생부유(MazumotowaseFuyu)' 를 모본으로, 불완전단감인 '서촌조생(Nishimurawase)'을 부 본으로 육성된 계통으로 감삽의 정도 불완전단감이라 할 수 있다. '송본조생부유(MazumotowaseFuyu)'와는 0.53 의 유사 도를, '서촌조생(Nishimurawase)'과는 0.54의 유사도를 보였 는데, 완전단감인 '고성 따베감(Gogseung-Tabaegam)'과는 0.75 의 높은 유연관계를 보여 품종 감삽특징과 육종계보와는 상반된 결과를 보였다.

SSR 마커를 이용한 UPGMA cluster 분석결과를 전반적으 로 고찰 해볼 때, SSR 마커의 다형성에 따른 품종군의 분류결 과가 탈삽의 특성을 기준으로 분류한 품종군과 대체로 일치 함을 알 수 있었다. 또한 품종군간의 유연관계에 있어서도 완 전단감군은 불완전 단감군과, 그리고 완전 떫은감은 불완전 떫은감군과 유연관계가 더욱 높은 것으로 관찰되었다.

본 연구에 사용된 20개의 SSR primer 들은 유럽의 감품종의 DNA 염기서열분석으로부터 개발되었지만, 일본 및 국내 품 종의 연구에서도 효과적으로 사용될 수 있어, 앞으로 감 유전 체 연구에 활용도가 더욱 증가할 것으로 예상된다. 또한 이들 마커들을 통해, 48 개 품종 중 '청도반시(Cheongdo-Bansi)'와 '경산반시(Gyeongsan-Bansi)'를 제외한 모든 품종간 구별이 가능하였으며, 이는 향후 신품종개발시 품종보호를 위한 품종 특이적 마커로 효율적으로 사용될 수 있음을 보여준다.

\section{감사의 글}

이 논문은 부산대학교 자유과제 학술연구비(2년)에 의하여 연구되었음.

\section{References}

1. Baird, W. V., R. E. Ballard, S. Rajapakse, and A. G. Abbott. 1996. Progress in Prunus mapping and application of molecular markers to germplasm improvement. Hort. Science 31, 1099-1106.
2. Cho, D. H., I. J. Chun, S. T. Kwon., Y. S. Song, and Y. D. Chou. 2007. Genetic Relationships of Korean Astringent Persimmon Varieties Using AFLP Analysis. Kor. J. Hort. Sci. Technol. 25, 114-118.

3. Cho, S. K. and T. H. Cho. 1965. Studies on the local varieties of persimmon in Korea (in Korea with English summary). Res. Rep. RDA 8, 147-190.

4. Hagidimitriou, M., A. Katsiotis, G. Menexes, C. Pontikis, and M. Loukas. 2005. Genetic diversity of major Greek olive cultivars using molecular (AFLPs and RAPDs) markers and morphological traits. J. Amer. Sco. Hort. Sci. 130, 21-217.

5. Helentijaris, T., G. King, M. Slocum, D. Siedenstang, and S. Wegman. 1985. Restriction fragment length polymorphisms as probes for plant diversity and their development as tools for applied plant breeding. Plant Mol. Biol. 5, 109-118.

6. Ikegami, A., A. Kitajima, and K. Yonemori. 2005. Inhibition of flavonoid biosynthetic gene expression coincides with loss of astringency in pollination-constant, no-astringent (PCNA)-type persimmon fruit. J. Hort. Sci. Biotechnol. 80, 225-228.

7. Ikeda, I., M. Yamada, A. Kurihara, and T. Nishida. 1985. Inheritance of astringency in Japanese persimmon (in Japanese with English Summary). J. Japan. Soc. Hort. Sci. 54, $39-45$.

8. Jae, H. J, J. H. Hwang, Y. O. Park, S. C. Kim, Y. J. Lee, B. G. Son, and Y. H. Park, 2009. Evaluation of genetic relationships among persimmon (Diospyros kaki Thunb.) cultivars introduced and indigenous in Korea. Kor. J. Hort. Sci. Technol. 27, 448-455.

9. Kwon, Y., J. Moon, Y. Kwon, D. Park, W. Yoon, I. Song, and S. Yi. 2003. AFLP analysis for cultivar discrimination in radish and Chinese cabbage. Kor. J. Breed. 35, 319-328.

10. Kikuchi, A. 1948. Pomology-Part I.(in Japanese), pp. 347-400, Yokendo, Tokyo.

11. Kim, T. C. 1993. Taxonomic studies of persimmon (Diospyros kaki Thunb) by multivariate and isozyme analyese. Seoul Nat'l. Univ. ph.D. Disser. (in Korean).

12. Nei, M. and W. H. Lee. 1979. Mathematical model for studying genetic variation in terms of restriction endonucleases. Proc. Natl. Acad. Sci. USA. 76, 5296-5273.

13. Prado, M. J., M. T. Herreara, R. A. Vazquez, S. Rome, and M. V. Gonzalez. 2005. Microprapation of two selected male kiwifruit and analsyis of genetic variation with AFLP markers. HortScience 40, 740-746.

14. Rohlf, F. J. 2002. NTSYSpc: numerical taxonomy system, version 2.1. Exeter Publishing, Ltd., Setauket, N.Y.

15. Soriano, J. M., S. Pecchioli, C. Romero, S. Vilanova, G. Llacer, E. Giordani, and M. L. Badenes. 2006. Development of microsatellite markers in polyploid persimmon (Diospyros kaki Lf) from an enriched genomic library. Molecular Ecology Note 6, 368-370.

16. Williams, M. N. V., N. Pande, S. Nair, M. Mohan, and J. Bennett. 1991. Restriction fragment length polymorphism analysis of polymerase chain reaction products amplified from mapped loci of rice (Oryzasativa L.) genomic DNA. 
Theor. Appl. Genet. 82, 489-498.

17. Yonemori, K. and J. Matsushima. 1985. Property of development of the tannin cells from non-astringent and astringent type fruits of Japanese persimmon (Diospyros kaki) and its relationship to natural astringency. J. Japan. Soc. Hort. Sci. 54, 201-208.

18. Yonemori, K., M. Yamada, and A. Sugiura. 2000. Persimmon genetics and breeding. Plant Breed. Rev. 19, 191-225.

\section{초록 : 초위성 마커를 이용한 감(Diospyros kaki Thunb.)의 유연관계 분석}

황지현 · 박여옥 1 김성철 1 이용재 · 강점순 · 최영환 · 손병구 · 박영훈*

(부산대학교 생명자원과학부 원예생명과학과, ${ }^{1}$ 경상남도 농업기술원 단감연구소)

총 20개의 감 SSR primer set을 사용하여 완전단감(PCNA) 12품종, 불완전단감(PVNA) 13품종, 불완전 떫은감 (PVA) 15품종, 완전 떫은감 $(\mathrm{PCA}) 8$ 품종 등, 총 48 개 유전자원의 유전적 연관성을 분석하였다. 획득된 114 개의 다형성 밴드를 이용하여 UPGMA 방식으로 유사도 및 집괴분석을 수행한 결과 48개 품종들은 크게 2개의 그룹 (cluster)으로 나뉘어졌으며, 제 1 cluster는 다시 4 개의 subcluster를 형성하였다. 이는 탈삽의 특성을 기준으로 분류한 품종군과 대체로 일치 함을 알 수 있고, 품종군간의 유연관계에 있어서는 완전단감군은 불완전 단감군과, 그리고 완전 떫은감은 불완전 떫은감군과 유연관계가 더욱 높은 것으로 관찰되었다. 평균 유사도의 값은 0.499 였 고 품종간 가장 높은 유사도 값(0.954)를 나타낸 것은 '청도반시'와 '함안반시'였고, 가장 낮은 유사도 값(0.192)를 나타낸 것은 '대마반'과 '애탕'이었다. 본 연구에 사용된 2SSR primer 들은 유럽 감품종으로부터 개발되어 보고 되었지만, 일본 및 국내 품종의 연구에서도 효과적으로 사용될 수 있었고, 이들 마커들을 통해, 48 개 품종 중 청도 반시(Cheongdo-Bansi)와 경산반시(Gyeongsan-Bansi)를 제외한 모든 품종간 구별이 가능하였다. 이는 향후 신품 종 개발시 품종보호를 위한 품종 특이적 마커로 효율적으로 사용될 수 있음을 보여준다. 